\title{
Erratum to: New approaches to quantifying bioerosion by endolithic sponge populations: applications to the coral reefs of Grand Cayman
}

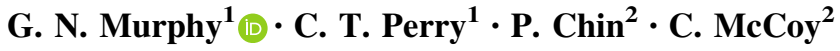

Published online: 21 April 2016

(C) Springer-Verlag Berlin Heidelberg 2016

\section{Erratum to: Coral Reefs \\ DOI 10.1007/s00338-016-1442-z}

Author corrections were overlooked in the original publication and now have been properly incorporated in the revised version.

The online version of the original article can be found under doi:10.1007/s00338-016-1442-z.

\section{G. N. Murphy}

gnm203@exeter.ac.uk

1 Geography, College of Life and Environmental Sciences, University of Exeter, Exeter EX4 4RJ, UK

2 Department of Environment, 580 North Sound Road, P.O. Box 10202, Grand Cayman KY-1002, Cayman Islands 